\title{
The Application and Reaction Mechanism of Catalytic Ozonation in Water Treatment
}

\author{
Yifei Guo', Li Yang1, Xiaoliang Cheng ${ }^{2}$ and Xiangtao Wang ${ }^{1 *}$
}

${ }^{1}$ Institute of Medicinal Plant Development, Chinese Academy Of Medical Sciences, Peking Union Medical College, 151 Malianwa North Road, Beijing 100094, P. R. China ${ }^{2}$ Mailstop 977-180A, Life Sciences Division, Lawrence Berkeley National Lab, 717 Potter St, Berkeley, CA 94710

\begin{abstract}
Pharmaceuticals and personal care products (PPCPs) are considered as the emerging environmental problem in the recent years. The elimination of PPCPs during water treatment are investigated at lab through different advanced oxidation processes (AOPs), which are the technologies based on the intermediacy of hydroxyl and other radicals to oxidize pollutants. Catalytic ozonation is proved as an effective technology for the removal of organics from wastewater. The paper presents a short review about the introduction of the ozonation catalysts and the reaction mechanism of the catalytic ozonation. The main aim is to provide a new and effective method in the removal of PPCPs in the aqueous solution.
\end{abstract}

Keywords: Pharmaceuticals; Ozone; AOPs; Catalyst; Catalytic ozonation

\section{Introduction}

The demand for fresh water is increasing with the growth in world population, and obtaining an adequate supply of clean water has likely been the challenge for many countries. To solve this problem, using water from unconventional sources is the best method from economic point of view. To make wastewater reuse safety, all the pollutants including biodegradable organic matter [1,2], pathogens [3], and micropollutants [4] presented at wastewater should be removed completely.

Every year the large number of pharmaceuticals and personal care products (PPCPs) enter the environment by the incomplete sewage treatment. PPCPs are now recognized as a new class of emerging environmental contaminants and brings increasing concern and scientific interests [5-7]. In recent years, there are numerous reports about the occurrences of PPCPs in wastewater, surface water, groundwater, and drinking water [8-11]. Even though the concentration of detected PPCPs in aqueous environment are low and often range from $\mathrm{ng} / \mathrm{L}$ to $\mu \mathrm{g} / \mathrm{L}$ levels, the potential dangers of PPCPs and their metabolites to human and ecological health exist due to many of them for some persistence in the body [12-14].

According to present knowledge, the elimination of PPCPs is mainly by the biological method [15], adsorption on activated carbon [16], reverse osmosis [17], and separation by membranes [18], ozonation $[19,20]$, photocatalysis [21], photo-Fenton [22,23], UV radiation [24]. Biological treatment is an environmentally friendly way with reasonable costs, but they are not adequate to treat non-biodegradable wastewaters and, usually, require a long period for micro-organisms to degrade the pollutants [25]. Thermal treatment at high temperature, although effective, is not economically feasible. Chemical treatments are not resolving requiring a post-treatment [26]. Advanced oxidation processes (AOPs) were frequently selected as a water treatment option to remove refractory and toxic organic compounds present in water, however, the traditional AOPs, including photocatalysis and photoFenton can hardly meet the requirements of the practical applications, because the high cost and the low mineralization efficiency [27].

Ozone is used widely in water treatment technology because of its powerful oxidation [28-30]. However, it has been reported, in most cases, the ozonation cannot completely degrade organic compounds and sometimes produce toxic intermediates. In such cases, the efficiency of oxidation can be improved by employing ozone together with $\mathrm{H}_{2} \mathrm{O}_{2}$ or UV irradiation to generate free radicals, mainly hydroxyl radicals (HO•) with high oxidation potential [24,31], however they present some drawbacks such as the residual of $\mathrm{H}_{2} \mathrm{O}_{2}$ [32] , the shorter life and higher energy consumption of UV lamp [33].

As a new and the most promising development in the research of advanced oxidation water treatment, heterogeneous catalytic ozonation has been attracting the increasing interest due to its potentially higher effectiveness in the degradation, and mineralization of refractory organic pollutants and lower negative effect on water quality [34-37] So far, metals oxide (e.g. $\mathrm{MgO}[38], \mathrm{Co}_{3} \mathrm{O}_{4}[39,40], \mathrm{ZnO}$ [41], $\mathrm{TiO}_{2}$ [42], $\mathrm{Al}_{2} \mathrm{O}_{3}$ [43]), metal or metal oxides on supports (e.g. $\mathrm{Pr} / \mathrm{Al}_{2} \mathrm{O}_{3}$ [44], $\mathrm{Co} / \mathrm{Al}_{2} \mathrm{O}_{3}$ [45], $\mathrm{Au} / \mathrm{Bi}_{2} \mathrm{O}_{3}$ [46], $\mathrm{MnO}_{\mathrm{x}} / \mathrm{MWCNT}$ [37], $\mathrm{TiO}_{2} /$ silicagel [47], $\mathrm{TiO}_{2} / \mathrm{Al}_{2} \mathrm{O}_{3}$ [48]) have been reported as effective catalysts for ozonation processes. According to the previous investigation, two possible pathways of the heterogeneous catalytic ozonation can be speculated [49]: (1) enhancing $\mathrm{HO}$ - generation from aqueous ozone and (2) forming surface complexes between the carboxylic groups of the pollutants and the surface metal sites of the catalyst, which renders the coordinated pollutants more reactive towards molecular ozone. This paper gives a short review about the introduction of the ozonation catalysts and the mechanism of the catalytic ozonation.

\section{Ozonation}

The organic pollutants can be oxidized with ozone by direct or indirect pathways. The direct oxidation $\left(\mathrm{M}+\mathrm{O}_{3}\right)$ of organic pollutants by ozone is a selective reaction with slow reaction rate constants. The ozone molecule can directly react with the organic pollutants through

*Corresponding author: Xiangtao Wang, Institute of Medicinal Plant Development Chinese Academy of Medical Sciences, Peking Union Medical College, 151 Malianwa North Road, Beijing 100094, P. R. China, E-mail: xtwang@implad.ac.cn

Received June 15, 2012; Accepted July 05, 2012; Published July 08, 2012

Citation: Guo Y, Yang L, Cheng X, Wang X (2012) The Application and Reaction Mechanism of Catalytic Ozonation in Water Treatment. J Environ Anal Toxicol 2:150. doi:10.4172/2161-0525.1000150

Copyright: (c) 2012 Guo Y, et al. This is an open-access article distributed under the terms of the Creative Commons Attribution License, which permits unrestricted use, distribution, and reproduction in any medium, provided the original author and source are credited. 
1,3 dipolar cycloaddition, electrophilic, and nucleophilic reaction [50]. In water, only the former two reactions have been identified with many organics [51]. On the contrary, the nucleophilic reaction has been proposed in only a few cases in non-aqueous systems [52].

The indirect type of ozonation is due to the reactions of free radical species, especially the hydroxyl radical (HO•), with the organic matter present in water. These free radicals come from reaction mechanisms of ozone decomposition in water that can be initiated by the hydroxyl ion or, to be more precise, by the hydroperoxide ion.

The mechanism of ozone decomposition in water is pretty complicated, so far the most popular reaction model to explain the decomposition of ozone is the chain mechanism of Weiss, which the procedure is combined with initiation, propagation, and termination as follows $[53,54]$ (Table 1).

Supportive of this chain model, Bühler et al. proved experimentally that the $\mathrm{HO}$ radicals are dominant decomposition products of ozone in aqueous solutions, and accelerate the decomposition of ozone [55].

The rate of ozone decomposition in water is affected by $\mathrm{pH}$, which is accelerated in basic aqueous solution. Actually, several compounds could be the initiator, promoter, or inhibitor in nonpure water [56,57]. The Initiator $\left(\mathrm{OH}^{-}, \mathrm{H}_{2} \mathrm{O}_{2} / \mathrm{HO}_{2}, \mathrm{Fe}^{2+}\right)$ can lead to the formation of $\bullet \mathrm{O}_{2}^{\otimes}$ in the decomposition of ozone. The promoters $\left(\mathrm{R}_{2}-\mathrm{CH}-\mathrm{OH}\right.$, aryl- $(\mathrm{R})$, formate, humic substances, $\mathrm{O}_{3}$ ) are responsible for the regeneration of the $\cdot \mathrm{O}_{2}^{-}$ion from the hydroxyl radicals. The inhibitors $\left(\mathrm{CH}_{3}-\mathrm{COO}^{-}\right.$, alkyl- (R), $\mathrm{HCO}_{3}{ }^{-} / \mathrm{CO}_{3}{ }^{2-}$, humic substances) are compounds capable of consuming hydroxyl radicals without the regeneration of the superoxide anion.

In summary, the ozone reactions could be acted with unsaturated aromatic compounds, unsaturated aliphatic compounds, and some special functional groups. If the radical reaction is inhibited, the direct ozone reaction becomes more important. Ozone reaction is more inclined to direct reaction with increasing the inhibitor concentration. Therefore, inorganic carbon and organics show the substantial impact during these reactions.

Due to its high oxidation efficiency and environmentally friendly, ozone is widely used to oxidize the organic pollutants in water, however, it still remain problems. First, the utilization of ozone is low during the ozonation procedure, the solubility of ozone in water is poor, and there is a part of soluble ozone can be changed to $\mathrm{HO} \bullet$, which is nonselective oxidants $[58,59]$. Besides, comparing with other wastewater treatment methods, ozone is high cost to produce. Second, it is difficult to remove TOC and COD in water completely by ozonation. All these limit the development of ozonation.

\section{Catalytic Ozonation}

Catalytic ozonation has received increasing attention during past decades, due to its higher effectiveness in the degradation of organic pollutants. Organics can be oxidized by catalytic ozonation in the ambient temperature and pressure, which are difficult to dissociate by single ozonation. Catalytic ozonation shows great advantages in refractory organics in water, and is expected to be the powerful and valuable technology in water treatment. According to the different catalysts, catalytic ozonation can be divided to two kinds: one is the homogeneous catalytic ozonation, which is the metal ions as the catalysts present in the reaction system; the other is heterogeneous catalytic ozonation, the main catalysts are metal oxide and metal or metal oxide on supports.

\section{Homogeneous catalytic ozonation}

Transition metal ions $\left(\mathrm{Fe}^{2+}, \mathrm{Mn}^{2+}, \mathrm{Ni}^{2+}, \mathrm{Co}^{2+}, \mathrm{Cd}^{2+}, \mathrm{Cu}^{2+}, \mathrm{Ag}^{+}\right.$, $\mathrm{Cr}^{2+}, \mathrm{Zn}^{2+}$ ) are usually used as the catalysts in homogeneous catalytic procedure, to degrade the organic pollutants in water [60-65]. During this procedure, metal ions decide the rate of reaction system, the selectivity of ozone oxidation system, and the efficiency of ozone utilization.

The mechanism of homogeneous catalytic ozonation is based on an ozone decomposition reaction followed by the generation of hydroxyl radicals. The metal ions accelerate the decomposition of ozone to produce the $\bullet \mathrm{O}_{2}^{-}$, and then electron of $\bullet \mathrm{O}_{2}^{-}$transfer to $\mathrm{O}_{3}$ to gain $\bullet \mathrm{O}_{3}$, $\mathrm{HO} \cdot$ is accepted successfully [66]. In addition, as proposed by Pines and Reckhow [60], for a cobalt (II) oxalate/ozone system at $\mathrm{pH}$ 6, it is proposed that the first step in the reaction pathway is the formation of a cobalt (II) -oxalate complex. Cobalt (II) oxalate is then oxidized by ozone to form cobalt (III) oxalate. It is suspected that the site of attack is the metal center. The partial donation of electron density from oxalate to cobalt (II) may increase the reactivity of cobalt (II) oxalate as compared to free cobalt (II). The catalytic cycle is completed with the decomposition of cobalt (III) complex to form an oxalate radical and cobalt (II). The proposed reaction pathway for the ozonation of cobalt (II) -monooxalate complex is shown in Figure 1.

Homogeneous catalytic ozonation can effectively improve the efficiency of removal of organic pollutants in water, but the disadvantage of this technology is to introduce ions and result in the secondary pollution, which lead to increase the costs of water treatment.

\section{Heterogeneous catalytic ozonation}

Heterogeneous catalysts with higher stability and lower loss can improve the efficiency of ozone decomposition, and be recycled and reused without further treatment. Due to these advantages, the heterogeneous catalytic ozonation is used widely in water treatment. The efficiency of the catalytic ozonation process depends to a great extent on the catalyst and its surface properties as well as the $\mathrm{pH}$ of the solution that influences the properties of the surface active sites and ozone decomposition reactions in aqueous solutions [57]. The most important factor for heterogeneous system is the choice of catalysts. Now, the catalysts studied by researcher widely are metal oxides, and metals or metal oxides on supports.

$\begin{array}{ll}\text { Initiation } & \mathrm{O}_{3}+\mathrm{H}_{2} \mathrm{O} \rightarrow 2 \mathrm{HO} \cdot+\mathrm{O}_{2} \\ & \mathrm{O}_{3}+\mathrm{OH}^{-} \rightarrow \cdot \mathrm{O}_{2}^{-}+\mathrm{HO}_{2} \cdot \\ & \mathrm{O}_{3}+\mathrm{HO} \cdot \rightarrow \mathrm{HO}_{2} \cdot+\mathrm{O}_{2} \\ \text { Propagation } & \mathrm{O}_{3}+\mathrm{HO}_{2} \cdot \rightarrow \mathrm{HO} \cdot+2 \mathrm{O}_{2} \\ & 2 \mathrm{HO}_{2} \cdot \rightarrow \mathrm{H}_{2} \mathrm{O}_{2}+\mathrm{O}_{2} \\ & \text { Table } 1\end{array}$

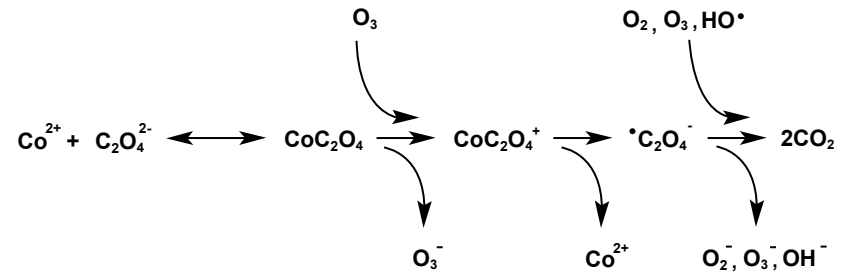

Figure 1: Proposed mechanism for oxalic acid catalytic ozonation by means of the $\mathrm{Co}(\mathrm{II}) / \mathrm{O}_{3}$ system. 
Metal oxides: The catalytic efficiency of metal oxides is decided by their physical and chemical properties. Physical properties include surface area, pore size, and surface charge. The main chemical properties include chemical stability, and active surface sites. Several researches claim that, some metal oxides, such as $\mathrm{Al}_{2} \mathrm{O}_{3}$ [67-69], $\mathrm{MnO}_{2}$ $[70,71], \mathrm{TiO}_{2}[72,73], \mathrm{ZnO}[41,74]$, and $\mathrm{FeOOH}[75,76]$ show excellent catalytic activity as the heterogeneous catalysts in degrading the organic pollutants in aqueous solution.

Metal or metal oxides on supports : The activity of supported catalysts is affected by the factors as follows: (1) the choice of the supports. The function of the catalyst supports is able to provide effective surface area and suitable pore structure, make the catalysts to obtain the excellent mechanical strength, thermal stability, and play the role of active center. In addition, the ordered mesoporous materials with larger surface area are suitable for catalyst supports. At present, the catalyst supports used widely are $\mathrm{TiO}_{2}, \mathrm{Al}_{2} \mathrm{O}_{3}$, activated carbon, and ceramic honeycomb and so on. (2) The active components of the catalysts. In general, the noble metal catalysts have the better catalytic activity than transition metal. However, due to the transition metal is relatively inexpensive, has higher thermal stability, and moderate mechanical strength, which lead to transition metal used widely in catalysts. (3) Preparation of the catalysts. The structure and dispersion of the catalysts are affected by the preparation method, so good catalyst preparation process can significantly improve the catalytic activity. Currently, the supports for heterogeneous system are including $\mathrm{Al}_{2} \mathrm{O}_{3}$, $\mathrm{TiO}_{2}$, active carbon, and clay; the active components are $\mathrm{Fe}, \mathrm{Co}, \mathrm{Mn}$, $\mathrm{Cu}, \mathrm{Ni}$ and so on $[35,37,44,77-86]$. The results show that the supported catalysts give excellent activity during the ozone decomposition.

Mechanism of heterogeneous catalytic ozonation: The three phases, including gaseous, liquid, and solid, are involved in aqueous heterogeneous catalytic ozonation. In addition, the catalytic process is affected by the kinds of catalysts, the target pollutants, and the $\mathrm{pH}$ value of solution, therefore, it is difficult to establish effective methods to track the process of reactive intermediates. Although some researchers have conducted several studies about the heterogeneous catalytic system, there is undefined conclusion. Two representative mechanisms are as follows:

(1) Interfacial reaction mechanism. In this mechanism, the main function of catalysts is to act as adsorptive material. First, using its large surface to adsorb and then remove the organic pollutants. Second, provide active adsorptive site and combine with aim molecules to form active complexes with lower activation energy, all of these make the pollutants could be oxidized simply by gaseous ozone and ozone or $\mathrm{HO} \bullet$ in solution. And then, the intermediates can be further oxidized in the surface of catalysts, or desorbed to the aqueous solution to be oxidized by ozone or HO. The procedure is shown in Figure 2 [59].

Legube et al. [59] proposed that, the catalyst would behave only as adsorbent $(\mathrm{Me}-\mathrm{OH})$; ozone and hydroxyl radical would be the oxidant species. Firstly, initial organic acid would be adsorbed on the surface of catalyst. Secondly, a strong negative charge would appear into the six or five-membered chelate ring at the surface. Lastly, the ozone or hydroxyl radical would oxidize the surface complex to give oxidation by-products either desorbed in solution or still adsorbed at the surface of catalyst (Figure 2).

Essentially, catalysts act as adsorptive materials in this mechanism, combine with organics to form the chelate that can be degraded by ozone or HO radical easier. This mechanism can explain the catalytic ozonation system with the good adsorptive properties. However, some heterogeneous catalytic process with poor adsorptive ability is difficult to be explained by this mechanism.

(2) HO• mechanism. This mechanism proposes that the metal oxide catalysts can increase the solubility of ozone and initiates the ozone decomposition. This mechanism speculates that surface hydroxyl groups of metal oxides play a vital role in the formation of HO. Soluble ozone in aqueous solution is adsorbed to the surface of the catalyst, a series of radical chain transfer are occurred to generate much $\mathrm{HO}$, which hold a high oxidation potential and can oxide the organic pollutants in wastewater. The catalytic ozonation system with poor adsorptive ability can be explained by this mechanism, the procedure is shown in Figure 3.

Legube et al. [59] also propose that in this mechanism, the catalyst would react with both ozone and adsorbed organics. Starting to the reduced catalyst, ozone would oxidize metal. The reaction of ozone on reduced metal could lead to HO radical. Organic acids would be adsorbed on oxidized catalyst and then oxidized by an electron-transfer reaction to give again reduced catalyst. The organic radical species A• would be then easily desorbed from catalyst and subsequently oxidized by $\mathrm{HO}$ or $\mathrm{O}_{3}$ either in bulk solution, or more probably, into the thickness of electric double layer (Figure 3).

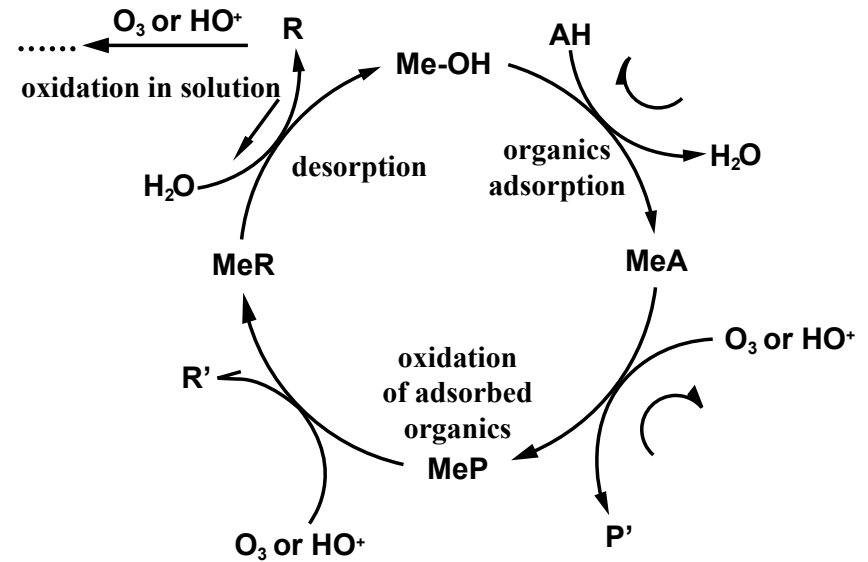

Figure 2: The mechanism for adsorption on catalyst and oxidation by ozone or $\mathrm{HO}$ radical of adsorbed organic.

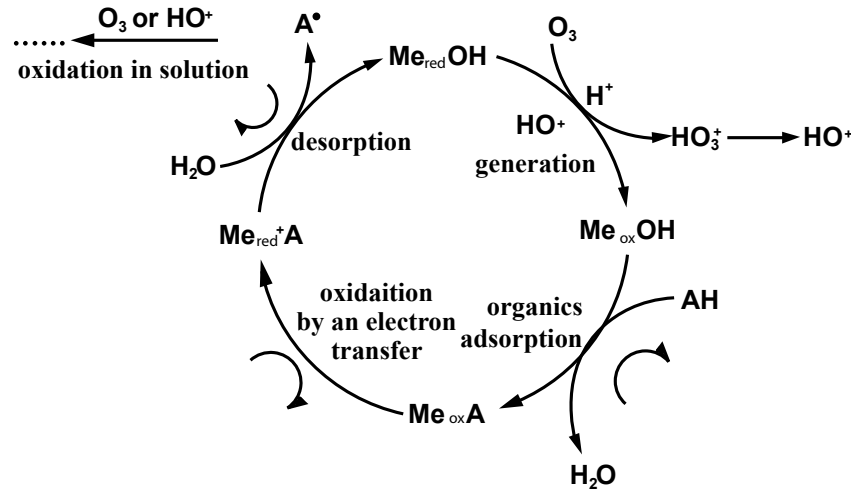

Figure 3: The possible mechanism for $\mathrm{HO}$ or other radical species generation by reaction of ozone with reduced metal of catalyst. 
(A) 0

Al Al

(C)

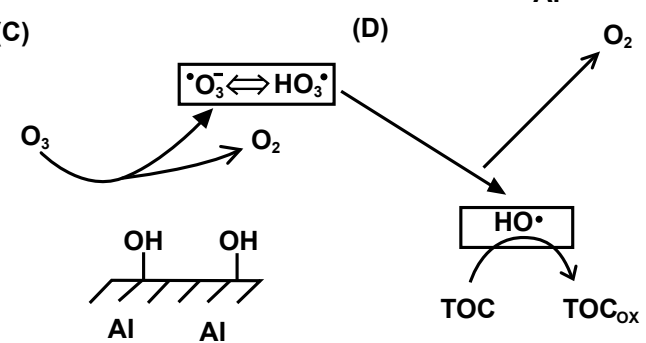

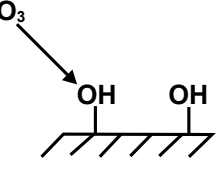

Figure 4: Suggested reaction mechanism during catalytic ozonation with $\mathrm{Al}_{2} \mathrm{O}_{3}$.

Ernst et al. [68] proposed, the adsorption of organics on the catalyst's surface would not be necessary to provide the catalytic effect, moreover, DOC adsorption would probably inhibit the effect due to an overlaying of hydroxyl groups. As can be seen from Figure 4, dissolved ozone adsorbs first on the catalyst's surface and then decomposes rapidly due to presence of hydroxyl surface groups. Due to the decomposition of ozone, active atomic oxygen is produced and reacted with alumina hydroxyl surface groups to form $\mathrm{O}_{2} \mathrm{H}^{-}$anions which subsequently can react very fast with another $\mathrm{O}_{3}$ to form $\mathrm{O}_{2} \mathrm{H}$ radicals or the $\mathrm{O}_{2} \mathrm{H}$ radicals can be produced directly. This radical reacts subsequently with another ozone molecule to generate an $\mathrm{O}_{3}{ }^{-}$radical. The $\mathrm{O}_{3}^{-}$radical decomposes into oxygen and a free $\mathrm{HO}$ radical which can oxidize organic compounds either in solution or on the surface or in a thin film layer above the surface of the catalyst (Figure 4)

Thus, during the process of pollutants degraded by heterogeneous catalytic ozonation, when the interfacial reaction occurs, and the characteristics of organics play the decisive role. The $\mathrm{pH}$ of solution affects the adsorption of organic pollutants on the catalyst surface, the adsorption is the rate controlling step of the interfacial reactions, which determines the removal degree of organic pollutants. For HO• mechanism, the activity of catalysts is related with the surface properties of metal oxides, especially the surface Lewis acid sites playing the important role in the catalytic reaction.

\section{Conclusions}

Ozone is an environmentally friendly oxidant, since it decomposes to $\mathrm{O}_{2}$ without producing self-derived byproducts in the oxidation reactions. The application of ozone in water treatment systems has experienced rapid growth in the past decades, including homogeneous and heterogeneous catalytic ozonation. Recent research has shown that heterogeneous catalytic ozonation are useful tools for studying fundamental problems, both the active components and the support play important roles in this system due to their desirable structure and surface characteristics that affect the properties of the surface active sites and the decomposition of pharmaceuticals and personal care products (PPCPs). Besides, in order to explain the process of heterogeneous catalytic ozonation, the reaction mechanisms are summarized in this paper.

\section{References}

1. Kondo K, Jin T, Miura O (2010) Removal of less biodegradable dissolved organic matters in water by superconducting magnetic separation with magnetic mesoporous carbon. Physica C 470: 1808-1811.

2. Williams MD, Pirbazari $M$ (2007) Membrane bioreactor process for removing biodegradable organic matter from water. Water Res 41: 3880-3893.

3. Golet EM, Alder AC, Giger W (2002) Environmental exposure and risk assessment of fluoroquinolone antibacterial agents in wastewater and river water of the Glatt Valley Watershed, Switzerland. Environ Sci Technol 36 3645-3651.

4. Janssens I, Tanghe T, Verstraete W (1997) Micropollutants: A bottleneck in sustainable wastewater treatment. Water Sci Technol 35: 13-26.

5. Khetan SK, Collins TJ (2007) Human pharmaceuticals in the aquatic environment: a challenge to Green Chemistry. Chem Rev 107: 2319-2364.

6. Zuehlke S, Duennbier U, Heberer T (2004) Determination of polar drug residues in sewage and surface water applying liquid chromatography-tandem mass spectrometry. Anal Chem 76: 6548-6554.

7. Kolpin DW, Furlong ET, Meyer MT, Thurman EM, Zaugg SD, et al. (2002) Pharmaceuticals, hormones, and other organic wastewater contaminants in U.S. streams, 1999-2000: a national reconnaissance. Environ Sci Technol 36: 1202-1211.

8. Mompelat S, Le Bot B, Thomas $O$ (2009) Occurrence and fate of pharmaceutical products and by-products, from resource to drinking water. Environ Int 35: 803 814

9. Heberer T (2002) Occurrence, fate, and removal of pharmaceutical residues in the aquatic environment: a review of recent research data. Toxicol Lett 131: 5-17.

10. Loraine GA, Pettigrove ME (2006) Seasonal variations in concentrations of pharmaceuticals and personal care products in drinking water and reclaimed wastewater in southern California. Environ Sci Technol 40: 687-695.

11. Behera SK, Kim HW, Oh JE, Park HS (2011) Occurrence and removal of antibiotics, hormones and several other pharmaceuticals in wastewate treatment plants of the largest industrial city of Korea. Sci Total Environ 409 : 4351-4360.

12. Pomati F, Castiglioni S, Zuccato E, Fanelli R, Vigetti D, et al. (2006) Effects of a complex mixture of therapeutic drugs at environmental levels on human embryonic cells. Environ Sci Technol 40: 2442-2447.

13. Pomati F, Netting AG, Calamari D, Neilan BA (2004) Effects of erythromycin tetracycline and ibuprofen on the growth of Synechocystis sp. and Lemna minor. Aquat Toxicol 67: 387-396.

14. Heckmann LH, Callaghan A, Hooper HL, Connon R, Hutchinson $\mathrm{TH}$, et al. (2007) Chronic toxicity of ibuprofen to Daphnia magna: Effects on life history traits and population dynamics. Toxicol Lett 172: 137-145.

15. Ericson JF (2007) An evaluation of the OECD 308 water/sediment systems for investigating the biodegradation of pharmaceuticals. Environ Sci Technol 41 : $5803-5811$.

16. Liu H, Deng H, Shi J (2012) Activated carbon and cerium supported on activated carbon applied to the catalytic ozonation of polycyclic aromatic hydrocarbons. $\mathrm{J}$ Mol Catal A: Chem (in press).

17. Escher $\mathrm{BI}$, Lawrence M, Macova M, Mueller JF, Poussade $\mathrm{Y}$, et al. (2011) Evaluation of contaminant removal of reverse osmosis and advanced oxidation in full-scale operation by combining passive sampling with chemical analysis and bioanalytical tools. Environ Sci Technol 45: 5387-5394.

18. Velizarov S, Crespo JG, Reis MA (2004) Removal of inorganic anions from drinking water supplies by membrane bio/processes. Rev Environ Sci Biotechnol 3: 361-380

19. DeWitte B, Dewulf J, Demeestere K, Van De Vyvere V, De Wispelaere P, et al. (2008) Ozonation of ciprofloxacin in water: HRMS identification of reaction products and pathways. Environ Sci Technol 42: 4889-4895.

20. Vieno NM, Härkki H, Tuhkanen T, Kronberg L (2007) Occurrence of pharmaceuticals in river water and their elimination in a pilot-scale drinking water treatment plant. Environ Sci Technol 41: 5077-5084.

21. Li W, Lu S, Qiu Z, Lin K (2011) Photocatalysis of clofibric acid under solar light in summer and winter seasons. Ind Eng Chem Res 50: 5384-5393.

22. Klamerth N, Malato S, Agüera A, Fernández-Alba A, Mailhot G (2012) Treatment of municipal wastewater treatment plant effluents with modified 
photo-Fenton as a tertiary treatment for the degradation of micro pollutants and disinfection. Environ Sci Technol 46: 2885-2892.

23. Hassan MM, Hawkyard CJ (2002) Decolourisation of aqueous dyes by sequential oxidation treatment with ozone and Fenton's reagent. J Chem Technol Biotechnol 77: 834-841.

24. Real FJ, Benitez FJ, Acero JL, Sagasti JJP, Casas F (2009) Kinetics of the chemical oxidation of the pharmaceuticals primidone, ketoprofen, and diatrizoate in ultrapure and natural waters. Ind Eng Chem Res 48: 3380-3388.

25. Liotta LF, Gruttadauria M, Di Carlo G, Perrini G, Librando V (2009) Heterogeneous catalytic degradation of phenolic substrates: catalysts activity. J Hazard Mater 162: 588-606.

26. Danis TG, Albanis TA, Petrakis DE, Pomonis PJ (1998) Removal of chlorinated phenols from aqueous solutions by adsorption on alumina pillared clays and mesoporous alumina aluminum phosphates. Water Res 32: 295-302.

27. Thiruvenkatachari R, Kwon TO, Jun JC, Balaji S, Matheswaran M, et al. (2007) Application of several advanced oxidation processes for the destruction of terephthalic acid (TPA). J Hazard Mater 142: 308-314.

28. Ternes TA, Meisenheimer M, McDowell D, Sacher F, Brauch HJ, et al. (2002) Removal of pharmaceuticals during drinking water treatment. Environ Sci Technol 36: 3855-3863.

29. Zwiener C, Frimmel FH (2000) Oxidative treatment of pharmaceuticals in water Water Res 34: 1881-1885.

30. Hua W, Bennett ER, Letcher RJ (2006) Ozone treatment and the depletion of detectable pharmaceuticals and atrazine herbicide in drinking water sourced from the upper Detroit River, Ontario, Canada. Water Res 40: 2259-2266.

31. Meunier L, Canonica S, von Gunten U (2006) Implications of sequential use of UV and ozone for drinking water quality. Water Res 40: 1864-1876.

32. Canton C, Esplugas S, Casado J (2003) Mineralization of phenol in aqueous solution by ozonation using iron or copper salts and light. Appl Catal B: Environ 43: $139-149$

33. Hofbauer DEW, Andrews SA (2004) Influence of UV irradiation and UV hydrogen peroxide oxidation process on natural organic matter fluorescence characteristics. Water Sci Technol: Water Supply 4: 41-46.

34. Yang L, Hu C, Nie Y, Qu J (2009) Catalytic ozonation of selected pharmaceuticals over mesoporous alumina-supported manganese oxide. Environ Sci Techno 43: 2525-2529.

35. Rosal R, Gonzalo MS, Rodríguez A, García-Calvo E (2010) Catalytic ozonation of fenofibric acid over alumina-supported manganese oxide. J Hazard Mater 183: $271-278$.

36. Chetty EC, Maddila S, Southway C, Jonnalagadda SB (2012) Ozone initiated $\mathrm{Ni} /$ Metal oxide catalyzed conversion of 1,2-Dichlorobenzene to mucochloric acid in aqueous solutions. Ind Eng Chem Res 51: 2864-2873.

37. Sui M, Xing S, Sheng L, Huang S, Guo H (2012) Heterogeneous catalytic ozonation of ciprofloxacin in water with carbon nanotube supported manganese oxides as catalyst. J Hazard Mater 227-228: 227-236.

38. Moussavi G, Mahmoudi M (2009) Degradation and biodegradability improvement of the reactive red 198 azo dye using catalytic ozonation with MgO nanocrystals. Chem Eng J 152: 1-7.

39. Anipsitakis GP, Stathatos E, Dionysiou DD (2005) Heterogeneous activation of oxone using Co3O4. J Phys Chem B 109: 13052-13055.

40. Guo W, Su S, Yi C, Ma Z (2012) Degradation of antibiotics amoxicillin by Co3O4-catalyzed peroxymonosulfate system. Environ Prog Sustain (in press).

41. Zhai X, Chen Z, Zhao S, Wang H, Yang L (2010) Enhanced ozonation of dichloroacetic acid in aqueous solution using nanometer $\mathrm{ZnO}$ powders. J Environ Sci (China) 22: 1527-1533.

42. Song S, Liu Z, He Z, Zhang A, Chen J, et al. (2010) Impacts of morphology and crystallite phases of titanium oxide on the catalytic ozonation of phenol. Environ Sci Technol 44: 3913-3918.

43. Sharma YC, Srivastava V, Mukherjee AK (2010) Synthesis and application of nano-Al2O3 powder for the reclamation of hexavalent chromium from aqueous solutions. J Chem Eng Data 55: 2390-2398.

44. He Z, Zhang A, Song S, Liu Z, Chen J, et al. (2010) Al2O3 modified with praseodymium: An application in the heterogeneous catalytic ozonation of succinic acid in aqueous solution. Ind Eng Chem Res 49: 12345-12351.
45. Beltrán FJ, Rivas FJ, Montero-de-Espinosa R (2003) Mineralization improvement of phenol aqueous solutions through heterogeneous catalytic ozonation. J Chem Technol Biotechnol 78: 1225-1233.

46. Anandan S, Lee GJ, Chen PK, Fan C, Wu JJ (2010) Removal of orange II dye in water by visible light assisted photocatalytic ozonation using $\mathrm{Bi}_{2} \mathrm{O}_{3}$ and $\mathrm{Au} /$ $\mathrm{Bi}_{2} \mathrm{O}_{3}$ nanorods. Ind Eng Chem Res 49: 9729-9737.

47. Yang Y, Ma J, Zhang J, Wang S, Qin Q (2009) Ozonation of trace nitrobenzene in water in the presence of a $\mathrm{TiO}_{2} /$ silica-gel catalyst. Ozone: Sci Eng 31: 45-52.

48. Beltrán FJ, Rivas FJ, Montero-de-Espinosa R (2004) A TiO $/ \mathrm{Al}_{2} \mathrm{O}_{3}$ catalyst to improve the ozonation of oxalic acid in water. Appl Catal B: Environ 47: 101109

49. Zhang T, Li C, Ma J, Tian H, Qiang Z (2008) Surface hydroxyl groups of synthetic a-FeOOH in promoting $\cdot \mathrm{OH}$ generation from aqueous ozone: Property and activity relationship. Appl Catal B: Environ 82: 131-137.

50. Bailey PS (1958) The reactions of ozone with organic compounds. Chem Rev 58: 925-1010.

51. Decoret C, Royer J, Legube B, Dore M (1984) Experimental and theoretica studies of the mechanism of the initial attack of ozone on some aromatics in aqueous medium. Environ Technol Lett 5: 207-218.

52. Riebel AH, Erickson RE, Abshire CJ, Bailey PS (1960) Ozonation of carbonnitrogen double bonds. I. Nucleophilic attack of ozone. J Am Chem Soc 82 1801-1807.

53. Masschelein WJ (1992) Unit processes in drinking water treatment. Marce Dekker, Marcel Dekker, New York.

54. Weiss J (1935) Trans Faraday Soc 31: 668

55. Buehler RE, Staehelin J, Hoigne J (1984) Ozone decomposition in water studied by pulse radiolysis. 1. Perhydroxyl (HO2)/hyperoxide (O2-) and $\mathrm{HO} 3$ O3- as intermediates. J Phys Chem 88: 2560-2564.

56. Staehelin J, Hoigne J (1985) Decomposition of ozone in water in the presence of organic solutes acting as promoters and inhibitors of radical chain reactions. Environ Sci Technol 19: 1206-1213.

57. Kasprzyk-Hordern B, Ziólek M, Nawrocki J (2003) Catalytic ozonation and methods of enhancing molecular ozone reactions in water treatment. App Catal B: Environ 46: 639-669.

58. Andreozzi R, Insola A, Caprio V, Marotta R, Tufano V (1996) The use of manganese dioxide as a heterogeneous catalyst for oxalic acid ozonation in aqueous solution. Appl Catal A: Gen 138: 75-81.

59. Legube B, Karpel Vel Leitner N (1999) Catalytic ozonation: A promising advanced oxidation technology for water treatment. Catal Today 53: 61-72.

60. Pines DS, Reckhow DA (2002) Effect of dissolved cobalt(II) on the ozonation of oxalic acid. Environ Sci Technol 36: 4046-4051.

61. Wu CH, Kuo CY, Chang CL (2008) Homogeneous catalytic ozonation of C.I. Reactive Red 2 by metallic ions in a bubble column reactor. J Hazard Mater 154: 748-755.

62. Xiao H, Liu R, Zhao X, Qu J (2008) Effect of manganese ion on the mineralization of 2,4-dichlorophenol by ozone. Chemosphere 72: 1006-1012.

63. Trapido M, Veressinina Y, Munter R, Kallas J (2005) Catalytic ozonation of m-dinitrobenzene. Ozone: Sci Eng 27: 359-363.

64. Pachhade K, Sandhya S, Swaminathan K (2009) Ozonation of reactive dye, Procion red MX-5B catalyzed by metal ions. J Hazard Mater 167: 313-318.

65. Beltrán FJ, Rivas FJ, Montero-de-Espinosa R (2005) Iron type catalysts for the ozonation of oxalic acid in water. Water Res 39: 3553-3564.

66. Gracia R, Aragües JL, Cortés S, Ovelleiro JL (1995) In: Proceedings of the 12th world congress of the international ozone association. Lille, France: 75.

67. Qi F, Xu B, Chen Z, Ma J, Sun D, et al. (2009) Ozonation catalyzed by the raw bauxite for the degradation of 2,4,6-trichloroanisole in drinking water. J Hazard Mater 168: 246-252.

68. Ernst M, Lurot F, Schrotter JC (2004) Catalytic ozonation of refractory organic model compounds in aqueous solution by aluminum oxide. Appl Catal B: Environ 47: 15-25

69. Kasprzyk-Hordern B, Raczyk-Stanislawiak U, Swietlik J, Nawrocki J (2006) Catalytic ozonation of natural organic matter on alumina. Appl Catal B: Environ 62: 345-358. 
Citation: Guo Y, Yang L, Cheng X, Wang X (2012) The Application and Reaction Mechanism of Catalytic Ozonation in Water Treatment. J Environ Anal Toxicol 2:150. doi:10.4172/2161-0525.1000150

70. Dong Y, Yang H, He K, Song S, Zhang A (2009) B-MnO2 nanowires: A novel ozonation catalyst for water treatment. Appl Catal B: Environ 85: 155-161.

71. Tong SP, Liu WP, Leng WH, Zhang QQ (2003) Characteristics of MnO2 catalytic ozonation of sulfosalicylic acid and propionic acid in water. Chemosphere 50 1359-1364.

72. Rosal R, Gonzalo MS, Rodríguez A, García-Calvo E (2009) Ozonation of clofibric acid catalyzed by titanium dioxide. J Hazard Mater 169: 411-418.

73. Beltrán FJ, Rivas FJ, Montero-de-Espinosa R (2005) Iron type catalysts for the ozonation of oxalic acid in water. Water Res 39: 3553-3564.

74. Huang W, Fang G, Wang C (2005) A nanometer-ZnO catalyst to enhance the ozonation of 2,4,6-trichlorophenol in water. Colloid Surf A: Physicochem Eng Asp 260: 45-51.

75. Zhang T, Chen ZL, Ma J, Sui MH (2004) [Catalytic ozonation of trace nitrobenzene in water by iron hydroxide]. Huan Jing Ke Xue 25: 43-47.

76. Sui M, Sheng L, Lu K, Tian F (2010) FeOOH catalytic ozonation of oxalic acid and the effect of phosphate binding on its catalytic activity. Appl Catal B: Environ 96: 94-100.

77. Leitner NKV, Delanoe F, Acedo B, Legube B (2000) Reactivity of various Ru/ $\mathrm{CeO}_{2}$ catalysts during ozonation of succinic acid aqueous solutions. New J Chem 24: 229-233.

78. Zhao L, Ma J, Sun Z, Liu H (2009) Mechanism of heterogeneous catalytic ozonation of nitrobenzene in aqueous solution with modified ceramic honeycomb. Appl Catal B: Environ 89: 326-334.
79. Sui M, Liu J, Sheng L (2011) Mesoporous material supported manganese oxides (MnOx/MCM-41) catalytic ozonation of nitrobenzene in water. Appl Catal B: Environ 106: 195-203.

80. Beltrán FJ, Rivas FJ, Montero-de-Espinosa R (2005) Iron type catalysts for the ozonation of oxalic acid in water. Water Res 39: 3553-3564.

81. Rosal R, Gonzalo MS, Rodríguez A, Perdigón-Melón JA, García-Calvo E (2010) Catalytic ozonation of atrazine and linuron on $\mathrm{MnO}_{x} / \mathrm{Al}_{2} \mathrm{O}_{3}$ and $\mathrm{MnO}_{x} /$ SBA-15 in a fixed bed reactor. Chem Eng J 165: 806-812.

82. Fu H, Karpel Vel Leitner N, Legube B (2002) Catalytic ozonation of chlorinated carboxylic acids with $\mathrm{Ru} / \mathrm{CeO} 2-\mathrm{TiO} 2$ catalyst in the aqueous system. New J Chem 26: 1662-1666.

83. Zhao L, Sun Z, Ma J (2009) Novel relationship between hydroxyl radical initiation and surface group of ceramic honeycomb supported metals for the catalytic ozonation of nitrobenzene in aqueous solution. Environ Sci Technol 43: 4157-4163.

84. Skvortsova LN, Chukhlomina LN, Mokrousov GM, Batalova VN, Wu JJ (2012) Catalytic oxidation of phenol in the presence of iron-containing composites based on silicon and boron nitrides. Russ J Appl Chem 85: 41-45.

85. Xing S, Hu C, Qu J, He H, Yang M (2008) Characterization and reactivity of $\mathrm{MnO}(\mathrm{x})$ supported on mesoporous zirconia for herbicide 2,4-D mineralization with ozone. Environ Sci Technol 42: 3363-3368.

86. Zhang T, Li W, Croué JP (2011) Catalytic ozonation of oxalate with a cerium supported palladium oxide: an efficient degradation not relying on hydroxyl radical oxidation. Environ Sci Technol 45: 9339-9346. 